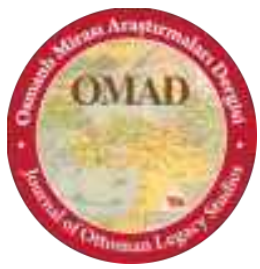

Osmanlı Mirası Araştırmaları Dergisi (OMAD), Cilt 4, Sayı 9, Temmuz 2017, ss. 69-84.

Journal of Ottoman Legacy Studies (JOLS), Volume 4, Issue 9, July 2017, pp. 69-84.

ISSN 2148-5704

DOI Number: 10.17822/omad.2017.66

Geliş Tarihi/Received: 04.04.2017 Kabul Tarihi/Accepted: 10.07.2017

\title{
BERGAMA, TEKKEDERE KÖYÜ SARI DEDE TÜRBESİ
}

\section{Sarı Dede Turbeh in Tekkedere Village, Bergama}

\section{Şakir ÇAKMAK ${ }^{*}$}

Özet: İzmir Bergama’ya bağlı Zeytindağ Beldesi, Tekkedere Köyü Mezarlığı'nda yer alan Sarı Dede Türbesi, birer kubbe ile örtülü iki birimli bir yapıdır. Ana mekân ile kuzeyindeki ön mekân, bir yuvarlak kemerle birbirine bağlanmıștır. Ön mekân, beşik tonozlu bir birim ile doğuya doğru genișletilmiștir. Devşirme taş bloklarla oluşturulmuş bir platform üzerine yığma sistemle inşa edilen yapının duvarları, alt kesimlerde bir sıra taş ve üç sıra tuğla, üst kesimlerde ise birer sıra taş ve tuğla ile almaşı düzende örülmüş, dikey birer tuğla ile kasetleme de yapılmıştır. Tüm cepheleri tuğladan iki sıra kirpi saçak ve kesme taş levhalarla oluşturulmuş düz bir saçak dolanmaktadır. Kubbeler kiremit kaplıdır. İnşa kitabesi bulunmamakla birlikte, malzeme ve bazı mimari unsurlarından hareketle 17. yüzyılda inşa edildiği anlaşılmaktadır. Halk arasında Sarı Dede ya da Sarı Baba gibi adlarla anılan yapının gerek Balkanlar gerekse Anadolu'da çok sayıda türbe, tekke ve zaviyesi bulunan Sarı Saltık ya da Sarı İsmail Sultan kültü ile ilişkili türbelerden biri olması mümkündür.

Anahtar Kelimeler: Bergama, Zeytindağ, Sarı Dede, Tekkedere, Türbe

Abstract: Sarı Dede Turbeh in Tekkedere Village graveyard (Zeytindağ, Bergama) is a two chamber building covered with two domes. The main chamber and the front part (ante-chamber) of the north are to connected to each other by a rounded arch. The ante-chamber was enlarged towards east with a section covered with barrel vault. It was built by reused material. Masonry was arranged in the following way: one row of stones followed by three rows of brick on the lower level and alternating rows of stone and brick on the upper level. The stones are framed by bricks surrounding each stone on all four sides. On all sides there are two rows of saw teeth and above which there is a flat eave made of flat stones. The domes are covered by brick. Even though no inscription survived, material and architectural features suggest that it was built in the $17^{\text {th }}$ century. The building, which is called Sar1 Dede or Sar1 Baba by the locals might have been one of turbehs of Sarı Saltık cult or Sarı İsmail Sultan cult that is widely spread around Asia Minor.

Key Words: Bergama, Zeytindağ, Sarı Dede, Tekkedere, Turbeh

Sarı Dede Türbesi, Bergama'nın Zeytindağ Beldesi, Tekkedere Köyü Mezarlığı'nda yer almaktadır. Tekkedere Köyü, Bergama'nın $20 \mathrm{~km}$ güneybatısında, İzmir-Çanakkale karayolunun yaklaşık $400 \mathrm{~m}$ doğusundadır. Mezarlık ise köyün yaklaşık $1 \mathrm{~km}$ güneyindedir.

Güneydoğu-kuzeybatı yönünde eğimli bir arazi üzerine, mezarlığın en yüksek noktasına inşa edilen yapıya, kuzeybatıdaki kabayonu taş, moloz taş ve devşirme mermer parçalarıyla oluşturulmuş merdiven basamaklarıyla ulaşılmaktadır. ${ }^{1}$ Halk arasında "Sarı Dede" ve "Sarı Baba" gibi adlarla anılan türbe, üzeri birer kubbe ile örtülü iki birimli bir yapıdır. Ana mekân ile kuzeyindeki ön mekân, geniş bir yuvarlak kemerle birbirine açılmaktadır. Ön mekân, içeriden

\footnotetext{
* (Yrd. Doç. Dr), Ege Üniversitesi, Edebiyat Fakültesi, Sanat Tarihi Bölümü, İzmir/Türkiye, e-mail: sakir.cakmak@ege.edu.tr, ORCID: orcid.org/0000-0001-7317-3023

1 İzmir Valiliğince restorasyonu planlanan yapının rölöve, restitüsyon ve restorasyon projeleri, bilimsel danışmanlığımda, Umart Mimarlık Ltd. Şti. tarafından hazırlanmıştır. Çizimleri kullanmama izin veren şirket sahipleri Mimar Burcu Tokgöz Kaplan ile İnşaat Mühendisi Mahir Kaplan'a ve çalışmada emeği geçen tüm Umart Mimarlık Ltd. Şti. elemanlarına teşekkürü borç bilirim.
} 
beşik tonoz örtülü bir hacimle ile doğuya doğru genişletilmiştir (Şekil 1). İnşa malzemesi ve yapım tekniği, ana mekân ve ön mekânın birlikte inşa edildiğini göstermektedir.

Yap1, arazideki eğim nedeniyle devşirme taş bloklarla oluşturulmuş bir platform üzerine yığma sistemle inşa edilmiştir. Duvar örgüsünde, farklı boyutlarda taş ve tuğlalar kullanılmıştır. Taşların bir kısmı devşirmedir. Duvarların alt kesimlerinde bir sıra taş ve üç sıra tuğladan oluşan almaşık duvar tekniği uygulanmıştır. Üst kesimler ise birer sıra taş ve tuğla ile yine almaşık düzende örülmüş, taşların aralarına dikey şekilde yerleştirilen birer tuğla ile kasetleme de yapılmıştır. Tüm cepheleri tuğladan iki sıra kirpi saçak ve kesme taş levhalarla oluşturulmuş düz bir saçak dolanmaktadır. Kubbeler kiremitle kaplıdır. Batı cephesi, yapının ana cephesidir (Şekil 2) (Resim 1). Türbenin girişi, ön mekânın batı cephesinden verilmiştir. Basık kemerli açıklık, söve olarak devşirme taş bloklara oturan bir yuvarlak kemer içerisine alınmıştır. İki kemer arasındaki alan ise yatay tuğla sıraları ile doldurulmuştur (Resim 2).

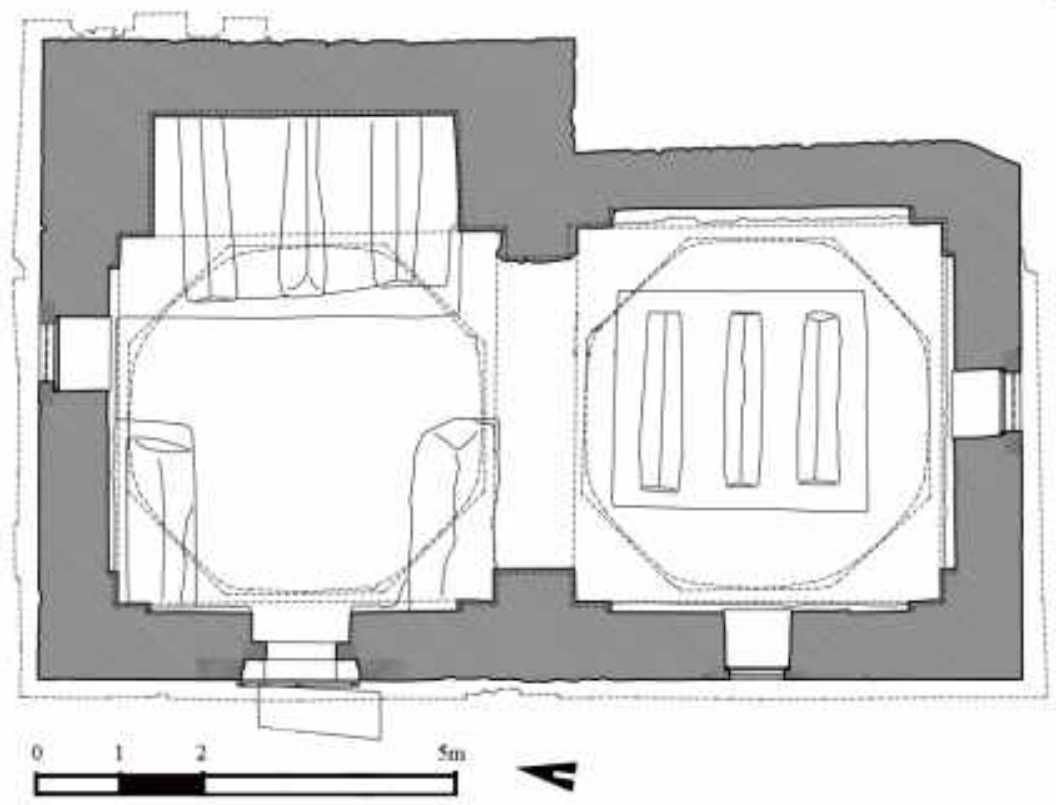

Şekil 1- Sarı Dede Türbesi. Plan. (Umart Mimarlık)

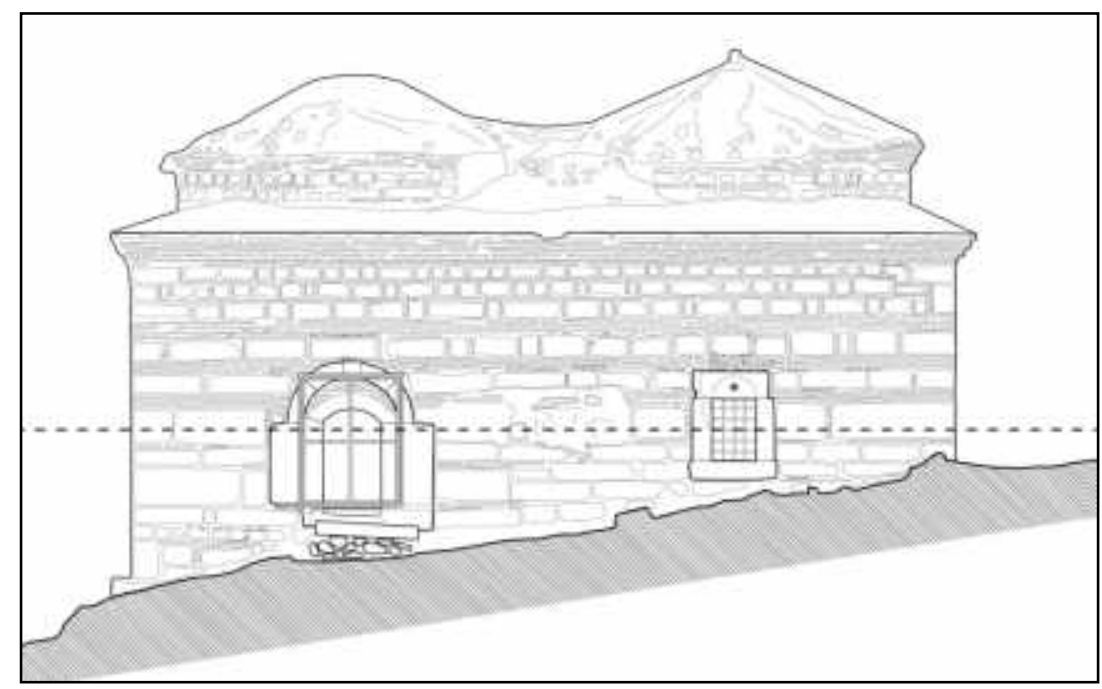

Şekil 2- Sarı Dede Türbesi. Batı cephesi. (Umart Mimarlık) 
Dış cephenin güneyinde, ön mekâna açılan dikdörtgen formlu bir pencere açıklığı mevcuttur (Resim 3). Açıklığın atk1 ve söveleri devşirme mermerdendir. Atkı taşı üzerinde yuvarlak kemer şeklinde bir silme ve altında bir gülbezek vardır. Atkı taşının söve ve duvarlarda kullanılan malzemeden farklı olması, yenilenmiş olabileceğini akla getirmektedir. Pencere, lokmalı demir parmaklıklara sahiptir.

Yapının ön mekânına açılan tek pencere açıklı̆̆ı, kuzey cephesindedir (Şekil 3) (Resim 4, 5). Kaş kemere sahip açıklık, mermerdendir. Açıklık, ön mekânı doğu yönüne doğru genişleten tonozlu birim de hesaba katıldığında, cephenin orta aksındadır. Kuzey cephesinde başka bir açıklık bulunmamaktadır. Yapının üzerine oturduğu, devşirme bloklarla meydana getirilmiş platformun en iyi şekilde gözlemlenebildiği cephe, kuzey cephesidir. Gerek platformda gerekse duvarlarda yoğun şekilde devşirme malzeme kullanılmış olması ve yapının batısındaki girlandlı lahit parçası (Resim 1), bu malzemelerin Tekkedere'nin yaklaşı $3 \mathrm{~km}$ güneyindeki antik Elaea kentinden taşınmış olabileceğini akla getirmektedir. ${ }^{2}$

Güney cephesinin ortasında, atkı ve söveleri devşirme taş bloklardan oluşan dikdörtgen formlu bir pencere açıklı̆̆ vardır (Şekil 4) (Resim 6). Açıklık, lokmalı parmaklıklara sahiptir. Başka bir açıklık bulunmayan cephe, bir saçak ile son bulmaktadır.

Güney cephesinin doğu kesiminde, kalan izlerden dikdörtgen planlı olduğu anlaşılan bir yapının temel ve molozları dikkati çekmektedir. Yoğun moloz dolgu nedeniyle tam olarak seçilemeyen yapı kalıntısının, görülebildiği kadarıyla cephedeki pencere açıklığını da kapatacak şekilde, kuru duvar tekniğiyle harçsız olarak inşa edilmiş yakın tarihli bir yapı olduğu anlaşılmaktadır (Resim 7).

Doğu cephesi, yapının herhangi bir açıklık içermeyen tek cephedir (Şekil 5) (Resim 8). Arazideki eğim nedeniyle, cephenin güney kesimi kuzey kesimine oranla hayli yüksektir. Doğu duvarı, kuzeydeki birimdeki genişletme nedeniyle kuzeye doğru bir kırık hatla devam etmektedir. Kuzey uçta, yapının üzerine oturduğu platform kısmen görülebilmektedir. Platformun taş bloklarında eksik ve kayıplar mevcuttur.

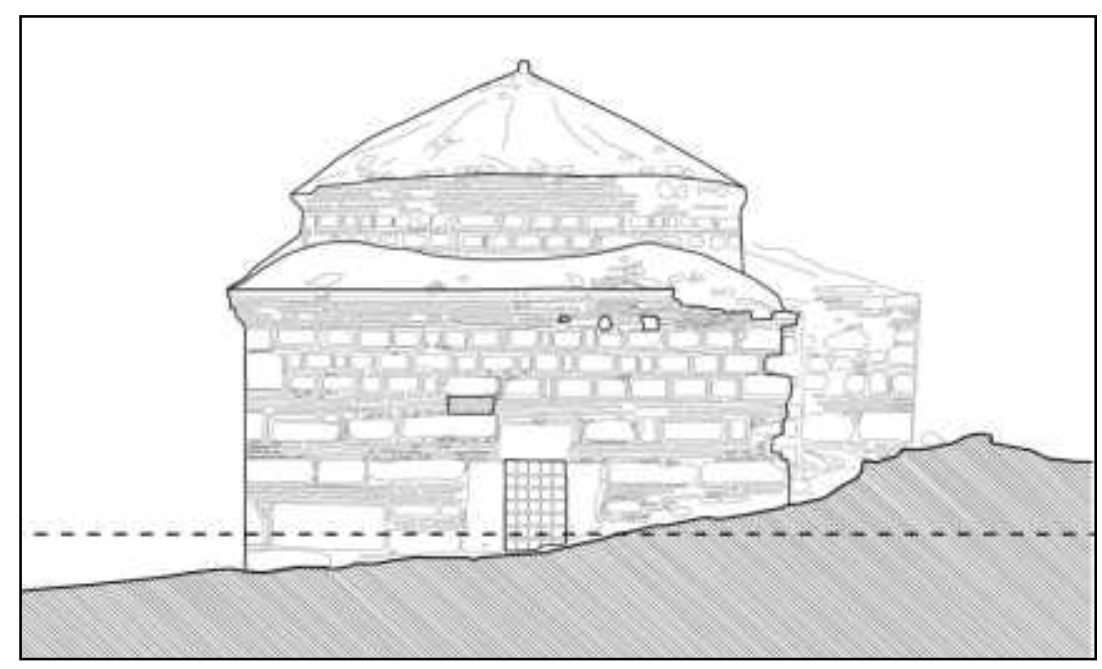

Şekil 3- Sarı Dede Türbesi. Kuzey cephesi. (Umart Mimarlık)

\footnotetext{
2 Felix Pirson, "Pergamon 2010-Yakın Çevrede Gerçekleştirilen Yüzey Araştırmaları Raporu”, 29. Araştırma Sonuçları Toplantısı, 1. Cilt, Ankara 2012, s. 429-460.
} 


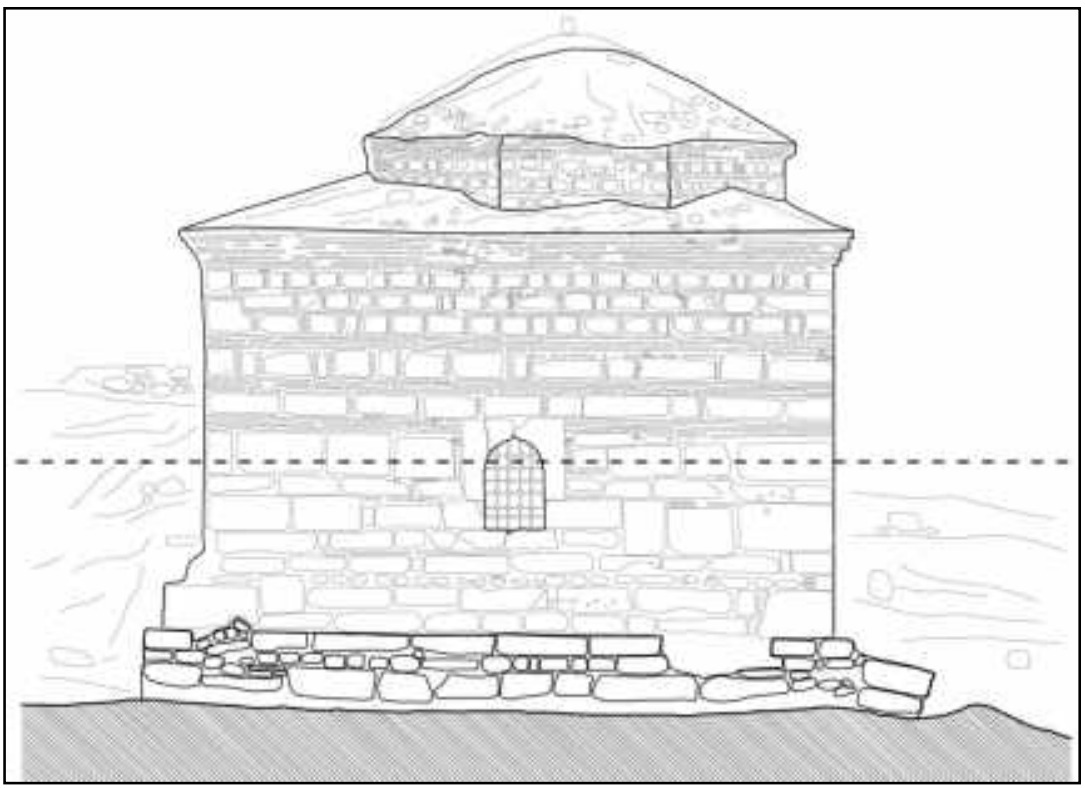

Şekil 4-Sarı Dede Türbesi. Güney Cephesi. (Umart Mimarlık)

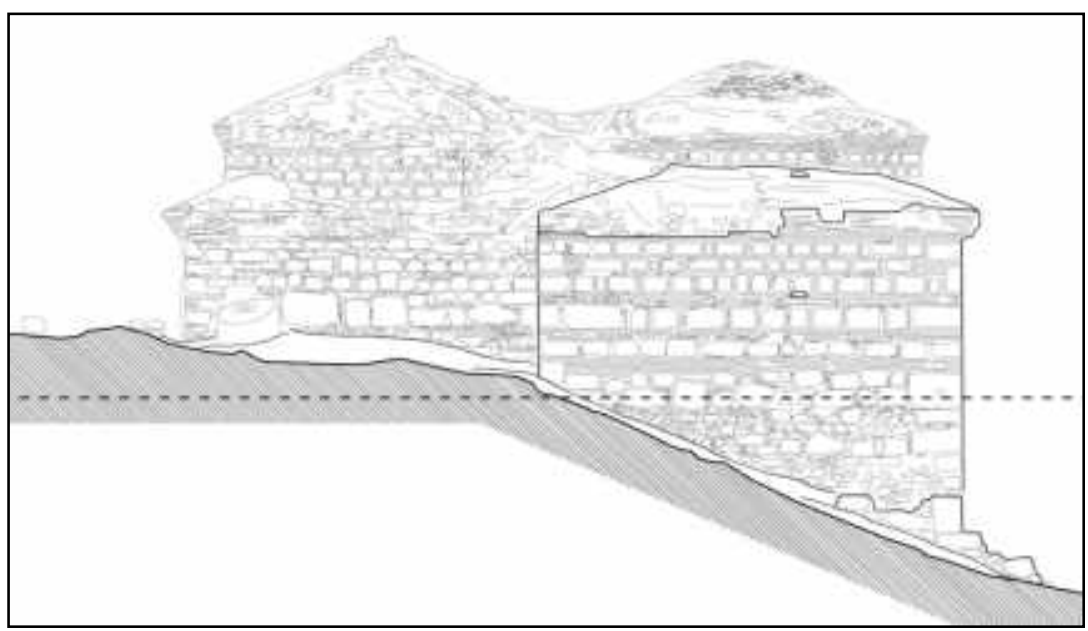

Şekil 5- Sarı Dede Türbesi. Doğu cephesi. (Umart Mimarlık)

Yapının tüm cephelerini tuğladan iki sıra kirpi saçak ve düzgün kesme taş levhalardan oluşan bir düz saçak sırası çevrelemektedir (Resim 9). Kuzey, güney ve batı cephelerindeki saçaklar önemli ölçüde korunmuş durumdayken doğu cephesindekiler hayli hasar görmüştür. Ancak bu cephenin de aynı saçak düzenine sahip olduğu kalan izlerden anlaşılabilmektedir.

Kubbeler tuğla ile örülmüş ve alaturka kiremitlerle kaplanmıştır. Her ikisinin de sekiz kenarlı birer kasnağı vardır (Resim 10). Cephelerden biraz daha içeri çekilmiş olan kasnaklar, duvarların üst kesimlerinde görülen almaşık düzeni sürdürmekte ve tuğladan iki sıra kirpi saçakla son bulmaktadır. Kasnakların kuzey, güney ve batı kesimleri büyük ölçüde korunmuş durumdayken, doğu kesimi hasar görmüştür.

Yukarıda da açıklandığı üzere, yapı kubbeyle örtülü iki birimden oluşmaktadır (Resim 11). Ön mekân, eyvanı andıran beşik tonozlu bir hacimle doğuya doğru genişletilmiştir (Resim 
12, 13). Ana mekân ise kare planlıdır (Resim 14). Ön mekândan ana mekâna bir yuvarlak kemer aracılığıyla geçiş sağlanmıştır. Ön mekânda üçü doğudaki beşik tonozlu hacmin içinde, ikisi kubbeyle örtülü birimin güneybatı ve kuzeybatı köşelerinde olmak üzere beş mezar bulunmaktadır. Ana mekânda ise hacmin ortasında yer alan bir platform üzerinde üç mezar yer almaktadır. Ana mekândaki mezarların ortadaki platform üzerinde bulunmasına karşılık, ön mekândaki mezarların dağınık biçimde yerleştirilmiş olması daha sonraki bir döneme ait olduklarını akla getirmektedir. Doğal taş ve sıvalarla taş sanduka görünümü verilmiş olan mezarlar, sonradan çeşitli müdahalelere maruz kalmış, özellikle ön mekânın güneybatı ve kuzeybatı köşelerindeki iki mezar çimento harçlı müdahalelerle bozulmuştur. Mezarların hiçbirinde mezar taşı yoktur.

Yapının zemini yakın bir tarihte yer seramikleriyle kaplanmıştır. Özgün zemin kaplaması görülememektedir.

İç duvarlar sıvalıdır. Dökülen sıvalardan, kemer, kubbe ve kubbe geçişlerinin tuğla ile örüldügü görülebilmektedir. Duvar yüzeyleri, üstte, köşelerde birleşen yuvarlak kemerli silmelerle hareketlendirilmiştir. Kubbe geçişleri, iki yandan bu kemerlere yaslanan mukarnas dolgulu pandantiflerle sağlanmıştır (Resim 15, 16). Mukarnas dizilerinden üst sırada olanlar, geçişler arasında yatay şekilde devam ederek, kubbe eteğinin altında bir süsleme şeridi meydana getirmektedir. Mukarnaslardan bazılarının sıvaları dökülmüş olmakla birlikte bir kısmı iyi korunmuş durumda günümüze kadar gelebilmiştir.

\section{Değerlendirme ve Sonuç}

Sarı Dede Türbesi'nin inşa kitabesi ya da inşa tarihi hakkında bilgi veren herhangi bir belge yoktur. Yapıdaki mezarların hiçbirinde mezar taşı mevcut değildir. Mezarlıkta mevcut taşların görülebilenleri de 19. yüzyıl ve sonrasına aittir.

Yap1, iki birimli kurgusuyla Anadolu türbeleri içinde "ön mekânlı türbeler" olarak da adlandırılan ve az sayıda örneği bulunan plan tipinin temsilcilerindendir. Anadolu Selçuklu, Beylikler ve Osmanlı dönemlerinde inşa edilen Anadolu türbeleri genellikle kare ya da çokgen gövdeli yapılardır. Anadolu Selçuklu dönemine ait türbelerin bir kısmında "mumyalık", "cenazelik" ya da "kripta" olarak adlandırılan mumyalanmış cenazenin konulduğu bir kat, bunun üzerinde bir gövde katı ve çoğunlukla içten kubbe, dıştan külah şeklinde bir örtü katı bulunur. Osmanlı türbelerinde ise 15. yüzyıl ortalarına kadar inşa edilmiş az sayıda örnek dışında mumyalık katı yoktur. Kare ya da çokgen gövde, çoğunlukla bir kubbe ile örtülüdür. ${ }^{3}$

Anadolu Türk mimarisinde, ön mekânlı türbe uygulamasına çok sık rastlanmamaktadır. Kırşehir Aşık Paşa Türbesi ${ }^{4}$ (1322), İznik, Kırgızlar Türbesi ${ }^{5}$ (14. yy. ortaları), Tire, Alihan Türbesi $^{6}$ (14. yy. birinci yarısı), Tire, Ali Baba Türbesi ${ }^{7}$ (15. yy. ortaları), Selçuk Şehabeddin Sivasi Türbesi (15. yy. ortaları) ${ }^{8}$ ve Milas-Ortaköy İkiz Türbe ${ }^{9}$ (17. yy.) birer ön mekân içeren az sayıdaki türbe örneklerindendir. Bu örneklerden, Milas-Ortaköy İkiz Türbe'nin sekizgen birimleri, birbirine sonradan eklenmiştir. Selçuk Şehabeddin Sivasi Türbesi’nde de farklı inşa

\footnotetext{
${ }^{3}$ Anadolu türbeleri hakkında ayrıntılı bilgi için bkz. Hakkı Önkal, Anadolu Selçuklu Türbeleri, Ankara 1996; Hakk1 Önkal, Osmanlı Hanedan Türbeleri, Ankara 1992; Mehmet Oluş Arık, "Erken Devir Anadolu-Türk Mimarisinde Türbe Biçimleri”, Anadolu (Anatolia), XI (1967), s.57-100; Orhan Cezmi Tuncer, Anadolu Kümbetleri, C.1, Ankara 1986; Orhan Cezmi Tuncer, Anadolu Kümbetleri, C.2, Ankara 1991; Ertan Daş, Erken Dönem Osmanlı Türbeleri, Gökkubbe Yayınları, İstanbul 2007.

${ }^{4}$ Oktay Aslanapa, Yüzyıllar Boyunca Türk Sanatı (14.yüzyll), İstanbul 1977, s. 192.

${ }^{5}$ Yıldız Ötüken-vd., Türkiye'de Vakıf Abideler ve Eski Eserler, IV, Ankara 1986, s. 339, şek.71.

${ }^{6}$ Hakkı Önkal, Tire Türbeleri, Ankara 1991, s.11, şek.1.

${ }^{7}$ H. Önkal, Tire Türbeleri....., s.71, şek.11.

${ }^{8}$ Şakir Çakmak, "Selçuk Türbeleri”, Birinci Uluslararası Geçmişten Günümüze Selçuk Sempozyumu (4-6 Eylül 1997), İzmir 1998, s. 378-380.

${ }^{9}$ Plan için bkz. Ersel Çağlitütüncügil, "Türk Türbe Mimarisinde Ender Bir Örnek: "Milas Ortaköy’de İkiz Türbe", XIII. Ortaçağ ve Türk Dönemi Kazıları ve Sanat Tarihi Araştırmaları Sempozyumu Bildirileri, 14-16 Ekim 2009, İstanbul 2010, s. 163.
} 
evrelerine işaret olabilecek bazı izler mevcuttur. Diğer örnekler ise özgünde iki birimli olarak tasarlanmış "ön mekânlı" yapılardır. Sonuç itibariyle benzer plan şemasına sahip örneklerin 1417. yüzyıllar arasına tarihlenen yapılar oldukları görülmektedir.

Yap1, taş ve tuğlanın birlikte kullanıldığı almaşık duvar tekniği ile örülmüş, üst kesimlerde dikey tuğlalarla kasetleme de yapılmıştır. Almaşık duvar tekniği, Beylikler Dönemi olarak adlandırdığımız 14 ve 15. yüzyıllarda Anadolu'nun özellikle batı kesimlerinde yaygın kullanım alanı bulmuştur. Aynı yoğunlukta olmamakla birlikte, sonraki yüzyıllarda da kullanılmaya devam edilmiştir. Afife Batur, almaşık duvar tekniğine ilişkin ayrıntılı çalışmasında, 14. yüzyıldan başlayarak tekniğin nasıl bir gelişim çizgisi izlediği hakkında somut değerlendirmeler yapmıştır. ${ }^{10}$ Batur, Ekrem Hakkı Ayverdi'ye dayanarak 14. yüzyılda tuğla boyutlarının $14 \times 28 \mathrm{~cm}$ ve $30 \times 30 \mathrm{~cm}$, kalınlığının ise genellikle $4 \mathrm{~cm}$ olduğunu belirttikten sonra, devam eden yüzyıllarda tuğla boyut ve kalınlıklarının değiştiğini ifade etmektedir. Sinan çağında $23 \times 33 \times 3,5 \mathrm{~cm}, 16 \times 33 \times 3,5 \mathrm{~cm}$ ve ayrıca $29 \mathrm{~cm}$ uzunlukta tuğlalar kullanıldığı, Batur'un saptamaları arasındadır. Sarı Dede Türbesi'nde yaptığımız incelemede, duvarlarda kullanılan tuğlaların çoğunlukla $33 \times 3,5 \mathrm{~cm}$ ve $29 \times 3,5 \mathrm{~cm}$, içteki kemerlerde kullanılan tuğlaların ise $23 \times 33 \times 3,5 \mathrm{~cm}$ boyutlarında olduğunu saptadık. Dolayısıyla tuğla boyutları, Batur'un Sinan çağına, yani 16. yüzyıla özgü olduğunu öne sürdüğü tuğla boyutlarıyla örtüşmektedir.

Her ne kadar tuğlalar, -Batur'un saptamalarından hareketle- 16. yüzyıl özellikleri gösterse de yapıda biraz daha geç bir tarihe işaret olabilecek bazı unsurlar da mevcuttur. Kuzey cephesindeki pencerede yer alan kaş kemer dışında, giriş açıklığından batı cephesindeki pencereye, kuzey ve güney birimleri ayıran ana kemere ve kuzey birimdeki eyvan kemerine varıncaya kadar yapıda kullanılan tüm kemerler, yuvarlak kemer formundadır. Yapının bu unsurlarında, herhangi bir onarımla bozulma ya da yenileme gibi bir müdahale de görülmemektedir. Anadolu mimarlığında Selçuklu döneminden 17. yüzyıl başlarına kadar kullanılan en yaygın kemer formu, sivri kemerdir. Bir başka deyişle 17. yüzyıl öncesinde yuvarlak kemer kullanımı yaygın değildir. ${ }^{11}$ Dolayısıyla tuğla boyutları bakımından 16. yüzyıl örnekleriyle örtüşmesine karşın, aynı boyutların özellikle taşrada kullanımının bir süre daha devam etmiş olabileceği ihtimali ve tüm kemerlerin yuvarlak formlu oluşu, yapının 17. yüzyılda inşa edildiğini düşündürmektedir.

Yöre halkı, yapının bir Bektaşi evliyası olarak kabul gören Sarı Dede ya da Sarı Baba adlı bir kişiye ait olduğunu ileri sürse de gerek bilimsel çalışmalarda gerekse yerel kaynaklarda, yapı ya da bu şahsa ilişkin bilgiye rastlanmamaktadır. Yapının, Balkanlar ve Anadolu'da çok sayıda türbe, tekke ve zaviyesi bulunan Sarı Saltık kültü ya da özellikle Batı Anadolu'da pek çok türbe ve makamı bulunan Sarı İsmail Sultan kültü ile bağlantılı türbelerden biri olması muhtemeldir. Her iki kült de Bektaşilikle ilişkilendirilmektedir.

Sarı Saltık, 13. yüzyılda yaşamış bir Türkmen aşiret evliyasıdır. Anadolu Selçuklu sultanı II. İzzeddin Keykavus'un isteği üzerine Karesi (Balıkesir) yöresindeki on iki bin kişilik aşireti ile birlikte bugünkü Romanya ve Bulgaristan sınırları içinde bulunan Dobruca'ya gittiği kabul edilmektedir. ${ }^{12}$ Sarı Saltık' ın Babaeski, İznik, Bor, Tunceli (Hozat), Diyarbakır gibi Anadolu kentlerinin yanı sıra pek çok Balkan kentinde de türbe ve makamları bulunmaktadır. ${ }^{13} 13$. yüzyılda yaşamasına karşın 16. yüzyıl başında Sultan II. Bayezid döneminde Balım Sultan tarafından kurulan Bektaşi tarikatı tarafından bir evliya gibi kabul edilmiş ve halifelik

\footnotetext{
${ }^{10}$ Afife Batur, "Osmanlı Camilerinde Almaşık Duvar Üzerine”, Anadolu Sanatı Araştırmaları, II, İstanbul 1970, s. 135-227.

11 Afife Batur, Osmanlı Camilerinde Kemer: Strüktür-Biçim Illişkisi Üzerine Bir Deneme (1300-1730),İstanbul Teknik Üniversitesi Mimarlık Fakültesi Baskı Atölyesi, İstanbul 1974, s.129.

${ }^{12}$ Ahmet Yaşar Ocak, Sarı Saltık: Popüler İslamın Balkanlar'daki Destani Öncüsü (XIII. Yüzyıl), Ankara 2011, s.60; Machiel Kiel, "Sarı Saltuk", Türkiye Diyanet Vakfi İslam Ansiklopedisi, C.36, s. 147-150.

${ }^{13}$ A.Y. Ocak, a.g.e.,s.15.
} 
makamına yerleştirilmiştir. ${ }^{14}$ Sarı İsmail Sultan da 13-14. yüzyıllar arasında yaşadığ kabul edilen ve özellikle Batı Anadolu'da Bektaşiler tarafindan hayli saygı gören bir kişidir. ${ }^{15}$ Gerçekten de Anadolu'da ve Balkanlar'da Sarı Dede, Sarı Baba, Sultan Sarı Baba gibi adlarla anılan ancak kime ait olduğu konusunda kesin verilere sahip olmadığımız pek çok türbe ve yatır mevcuttur. Bergama Sarı Dede Türbesi'nin de bu kültlerle ilişkili makam türbelerinden biri olabileceği akla gelmektedir. Yapının günümüzde daha çok Bektaşilerce ziyaret edilmesi de düşüncemizi destekler niteliktedir.

Sonuç olarak, Sarı Dede Türbesi, gerek Anadolu türbeleri arasında az sayıda örnekle temsil edilen bir plan şemasına sahip olması, gerekse duvar tekniği ve zengin mukarnas işçiliği bakımından özel bir yapıdır. Günümüze bazı küçük kayıplar dışında iyi korunmuş olarak ulaşan yapının, özgününe uygun bir şekilde restorasyonu ve çevre düzenlemesi yapılarak geleceğe aktarılması son derece önemli bir görevdir.

\section{Kaynakça}

Arık, Mehmet Oluş, "Erken Devir Anadolu-Türk Mimarisinde Türbe Biçimleri”, Anadolu (Anatolia), XI (1967), s.57-100.

Aslanapa, Oktay, Yüzyıllar Boyunca Türk Sanatı (14.yüzyıl), Milli Eğitim Bakanlığı Yayınları, İstanbul 1977.

Batur, Afife, "Osmanlı Camilerinde Almaşık Duvar Üzerine”, Anadolu Sanatı Araştırmaları, II, İstanbul, 1970, s. 135-227.

Batur, Afife, Osmanlı Camilerinde Kemer: Strüktür-Biçim İlişkisi Üzerine Bir Deneme (13001730), İstanbul Teknik Üniversitesi Mimarlık Fakültesi Bask1 Atölyesi, İstanbul 1974.

Çağlitütüncügil, Ersel, “Türk Türbe Mimarisinde Ender Bir Örnek: "Milas Ortaköy'de İkiz Türbe”, XIII. Ortaçă̆ ve Türk Dönemi Kazıları ve Sanat Tarihi Araştırmaları Sempozyumu Bildirileri, 14-16 Ekim 2009, İstanbul 2010, s.155-164.

Çakmak, Şakir, "Selçuk Türbeleri”, Birinci Uluslararası Geçmişten Günümüze Selçuk Sempozyuтu (4-6 Eylül 1997), İzmir 1998, s. 378-380.

Daş, Ertan, Erken Dönem Osmanlı Türbeleri, Gökkubbe Yayınları, İstanbul 2007.

Kiel, Machiel, "Sarı Saltuk”, Türkiye Diyanet Vakfi İslam Ansiklopedisi, C.36, İstanbul 2009, s. 147-150.

Ocak, Ahmet Yaşar, Sarı Saltık: Popüler İslamın Balkanlar'daki Destani Öncüsü (XIII. Yüzyıl), Türk Tarih Kurumu Yayınları, Ankara 2011.

Önkal, Hakkı, Tire Türbeleri, Kültür ve Turizm Bakanlığı Yayınları, Ankara 1991.

Önkal, Hakkı, Osmanlı Hanedan Türbeleri, Kültür Bakanlığı Yayınları, Ankara 1992.

Önkal, Hakkı, Anadolu Selçuklu Türbeleri, Atatürk Kültür Merkezi Yayınları, Ankara 1996.

Ötüken, Yıldız-vd., Türkiye'de Vakıf Abideler ve Eski Eserler, IV, Vakıflar Genel Müdürlüğü Yayınları, Ankara 1986.

Pirson, Felix, "Pergamon 2010-Yakın Çevrede Gerçekleştirilen Yüzey Araştırmaları Raporu", 29. Araştırma Sonuçları Toplantısı, 1. Cilt, Ankara 2012, s. 429-460.

Tuncer, Orhan Cezmi, Anadolu Kümbetleri, C.1, Ankara 1986.

\footnotetext{
${ }^{14}$ A.Y. Ocak, a.g.e.,s.107

${ }^{15}$ Rıza Sam-Yüksel Marım, “Denizli Tavas’ta Bektaşi Kültürünün Günümüze Yansıyan İzleri: Tekke Köyü Örneği”, Türk Kültürü ve Hacı Bektaş Veli Araştırma Dergisi, 2015/76, s.165-190.
} 
Tuncer, Orhan Cezmi, Anadolu Kümbetleri, C.2, Ankara 1991.

Sam Rıza-Marim, Yüksel, "Denizli Tavas’ta Bektaşi Kültürünün Günümüze Yansıyan İzleri: Tekke Köyü Örneği”, Türk Kültürü ve Hacı Bektaş Veli Araştırma Dergisi, 76, Ankara 2015, s.165-190. 


\section{Resimler:}

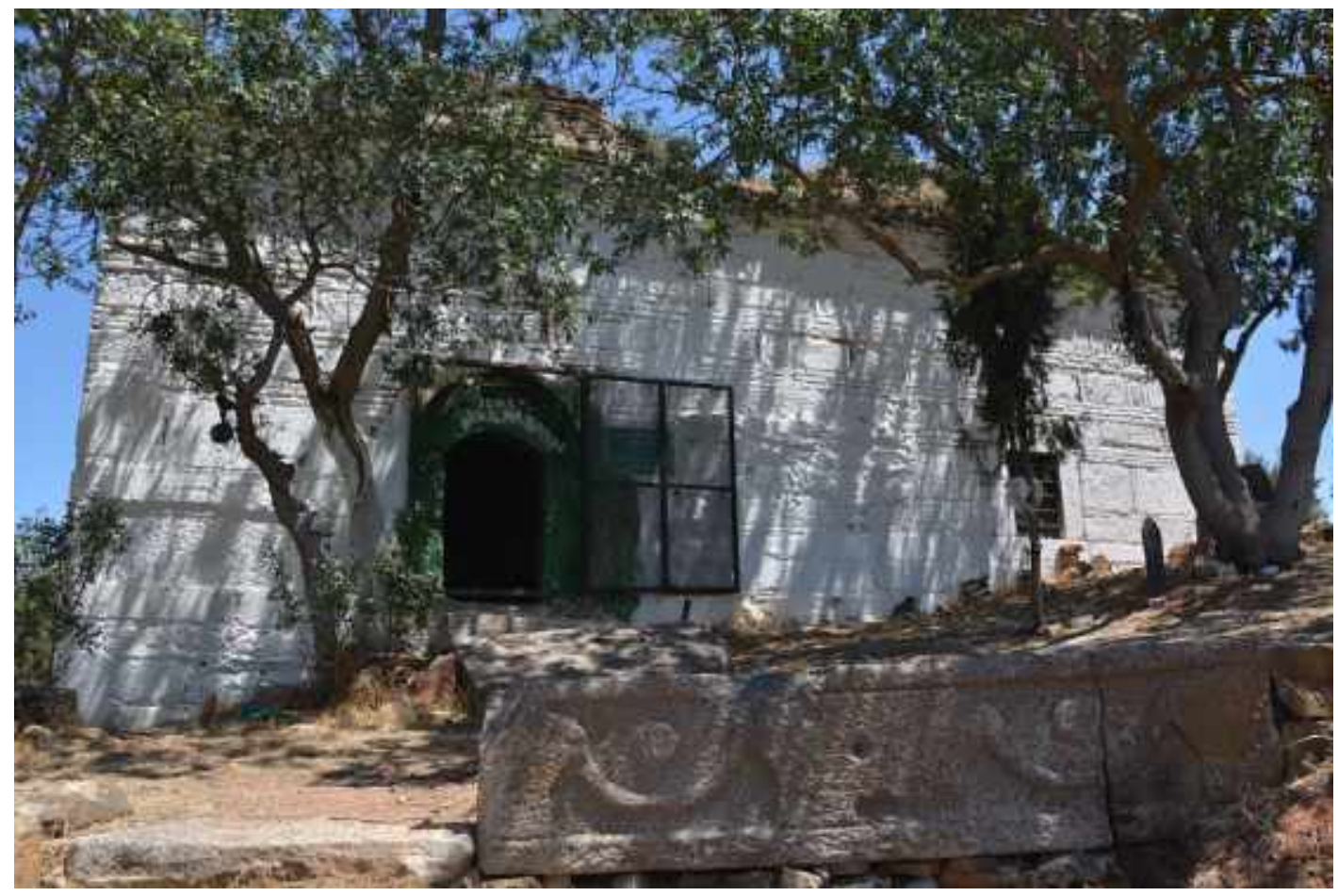

Resim 1-Sarı Dede Türbesi. Batı cephesi.

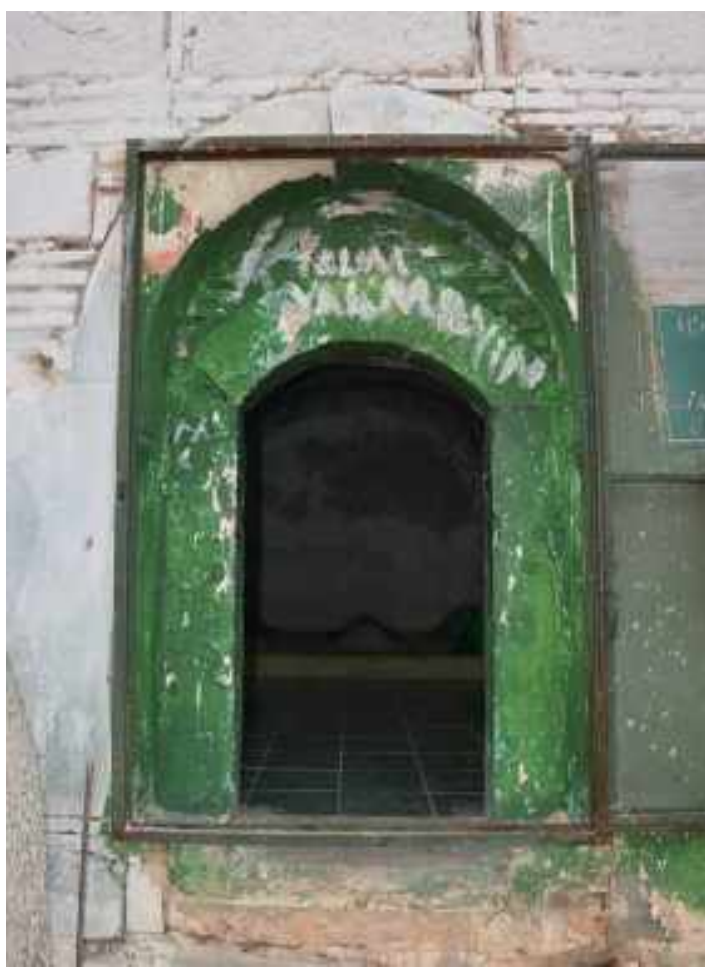

Resim 2- Sarı Dede Türbesi. Giriş açıklı̆̆ı.

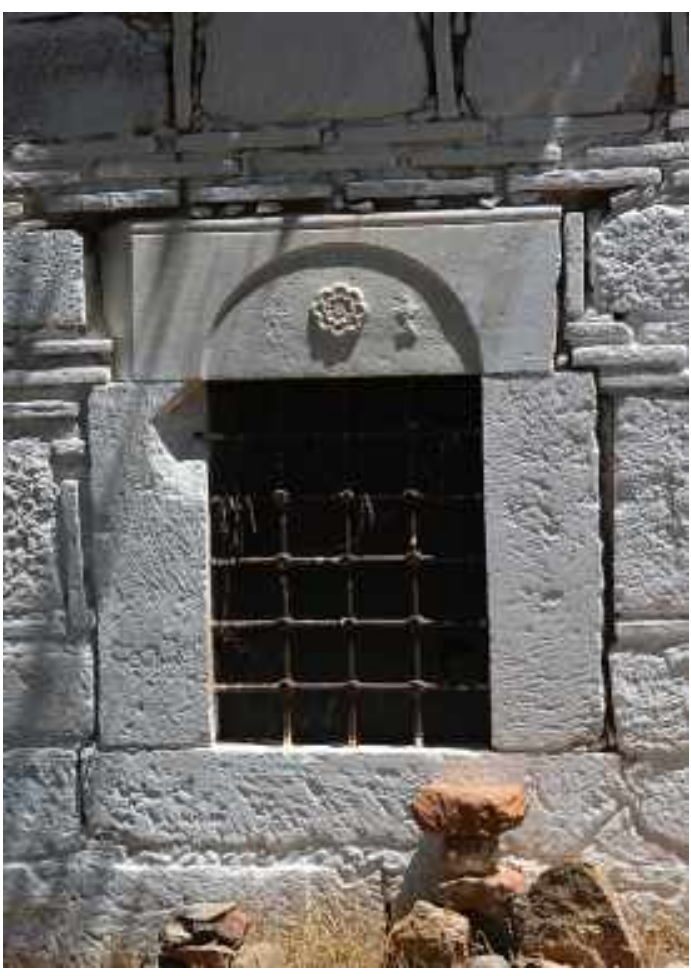

Resim 3-Sarı Dede Türbesi. Batı cephesindeki pencere. 


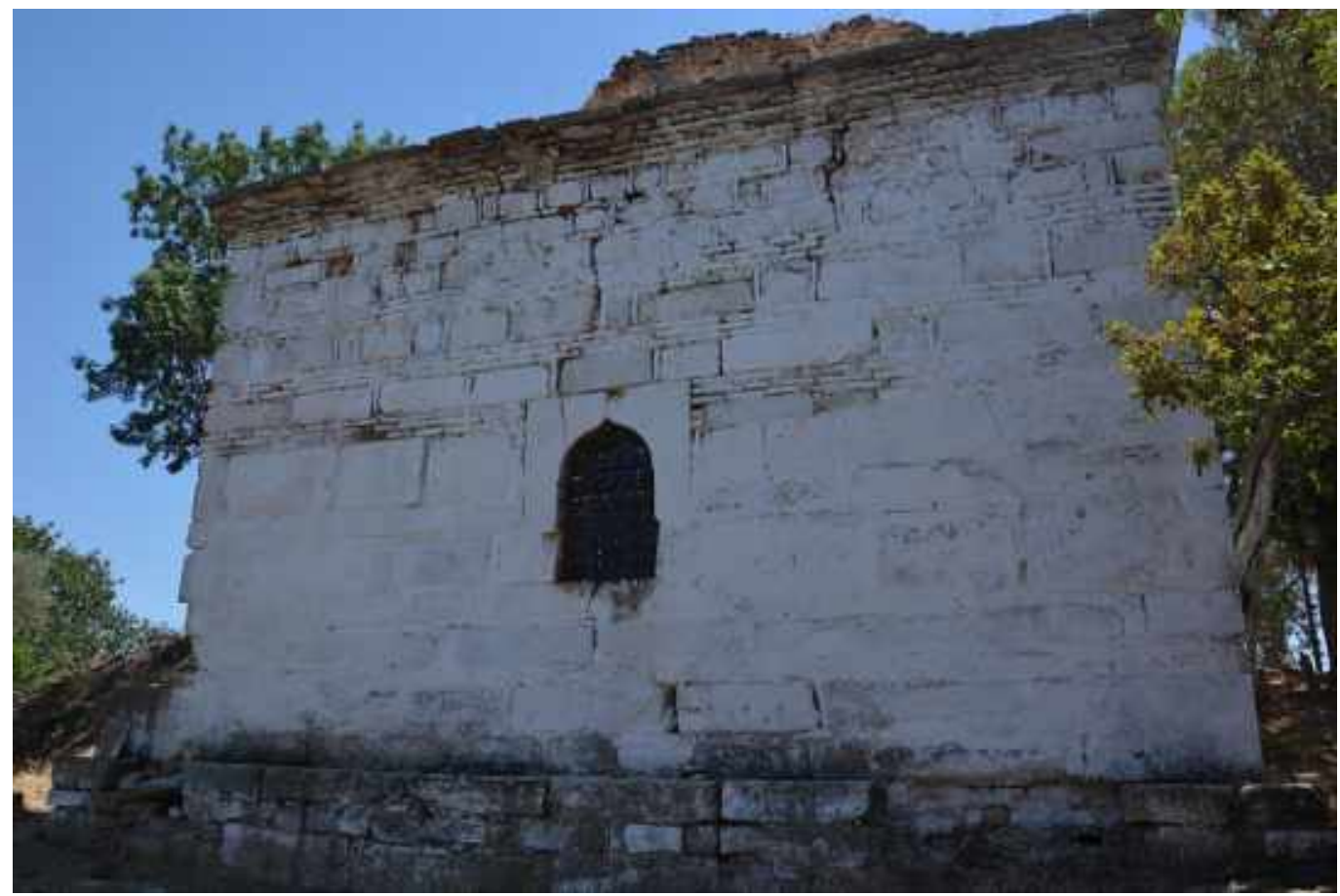

Resim 4-Sarı Dede Türbesi. Kuzey cephesi.

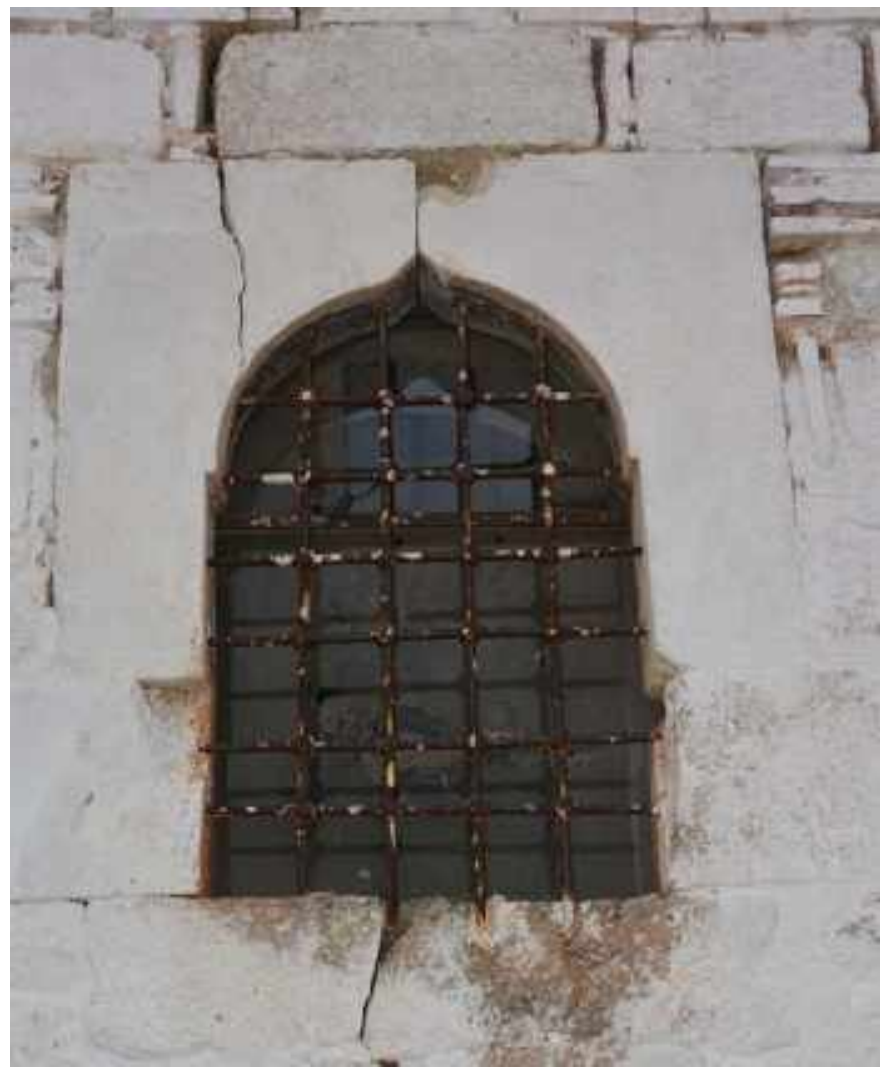

Resim 5-Sarı Dede Türbesi. Kuzey cephesindeki pencere. 


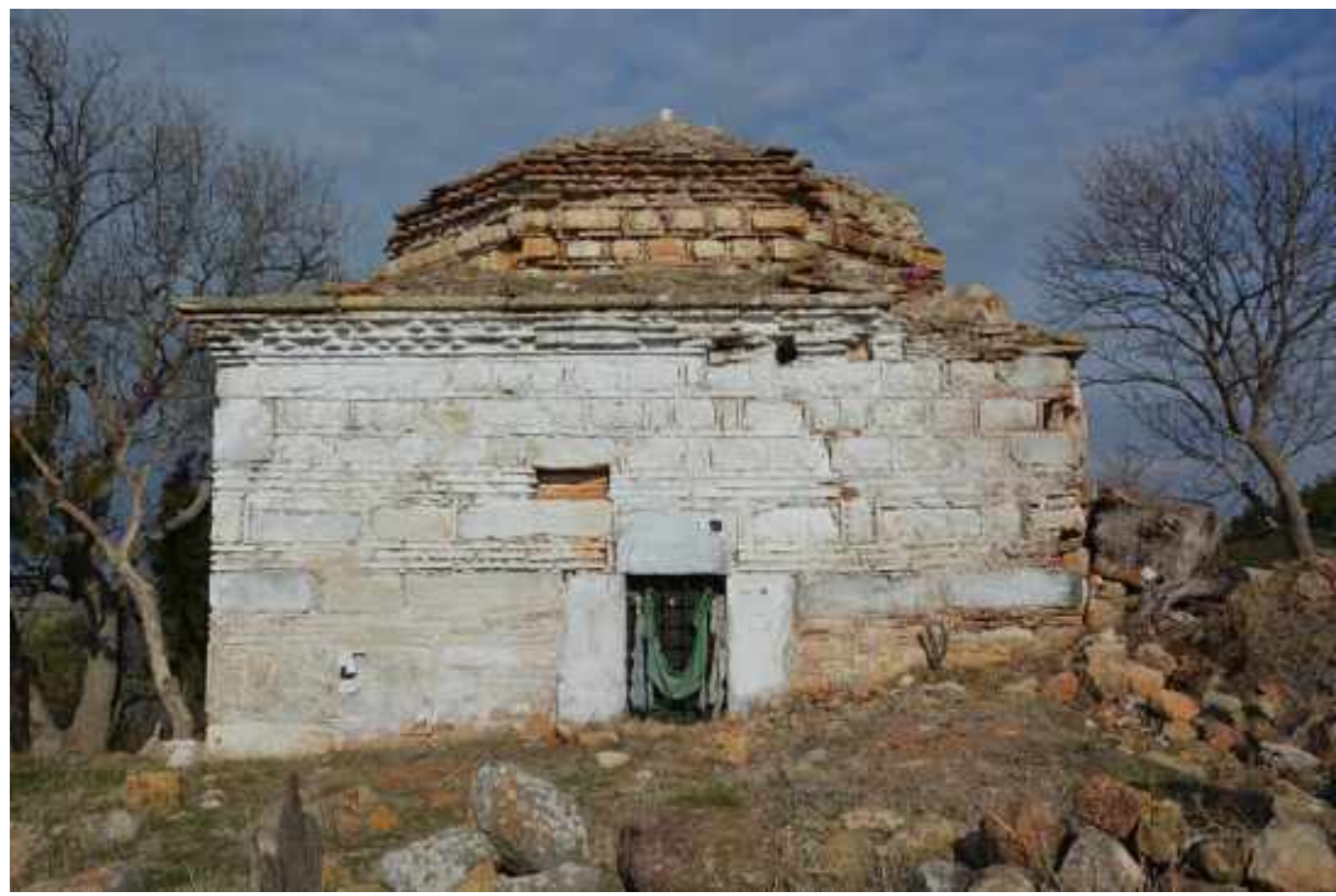

Resim 6-Sarı Dede Türbesi. Güney cephesi.

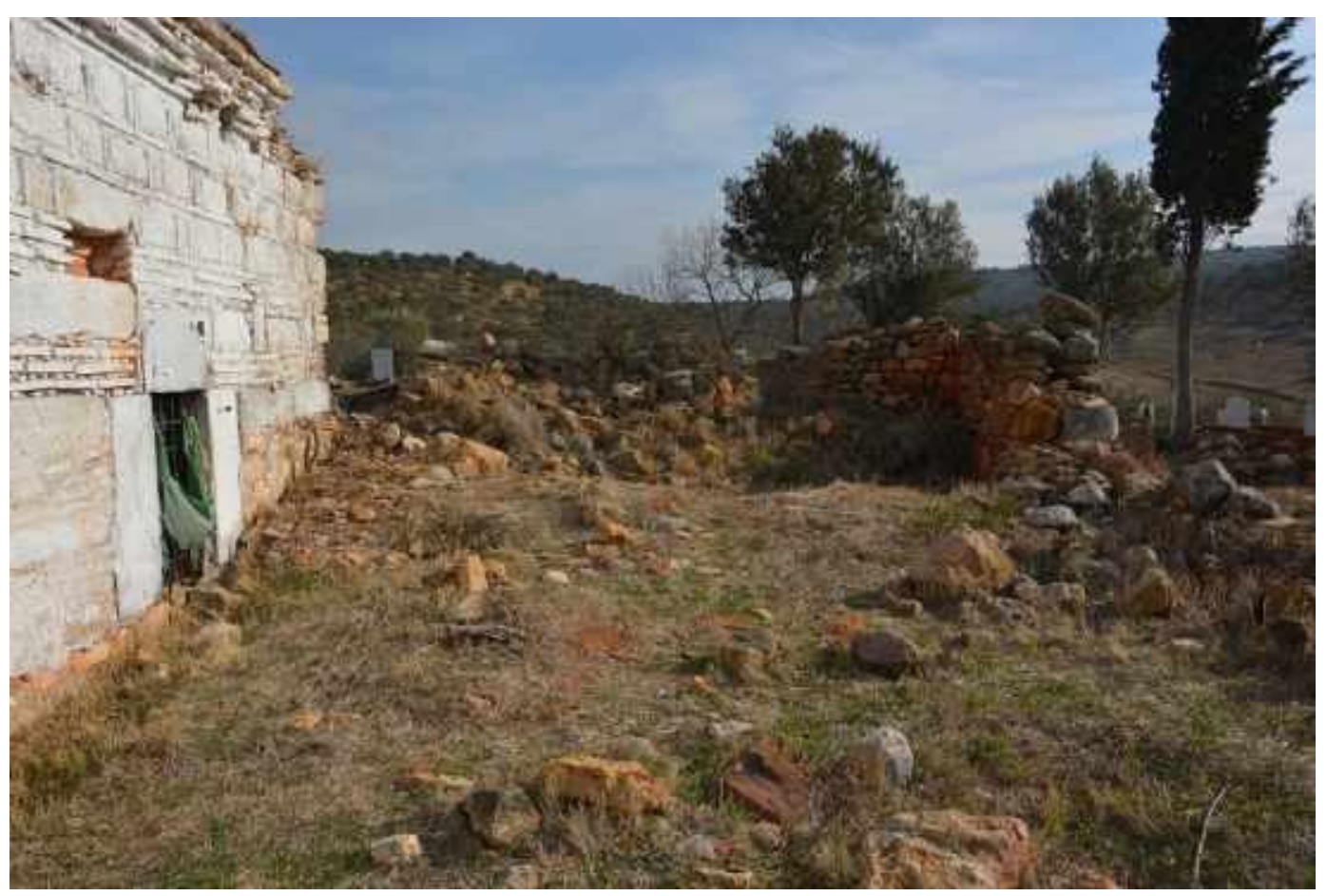

Resim 7-Sarı Dede Türbesi. Güneydeki yapı kalıntısı. 


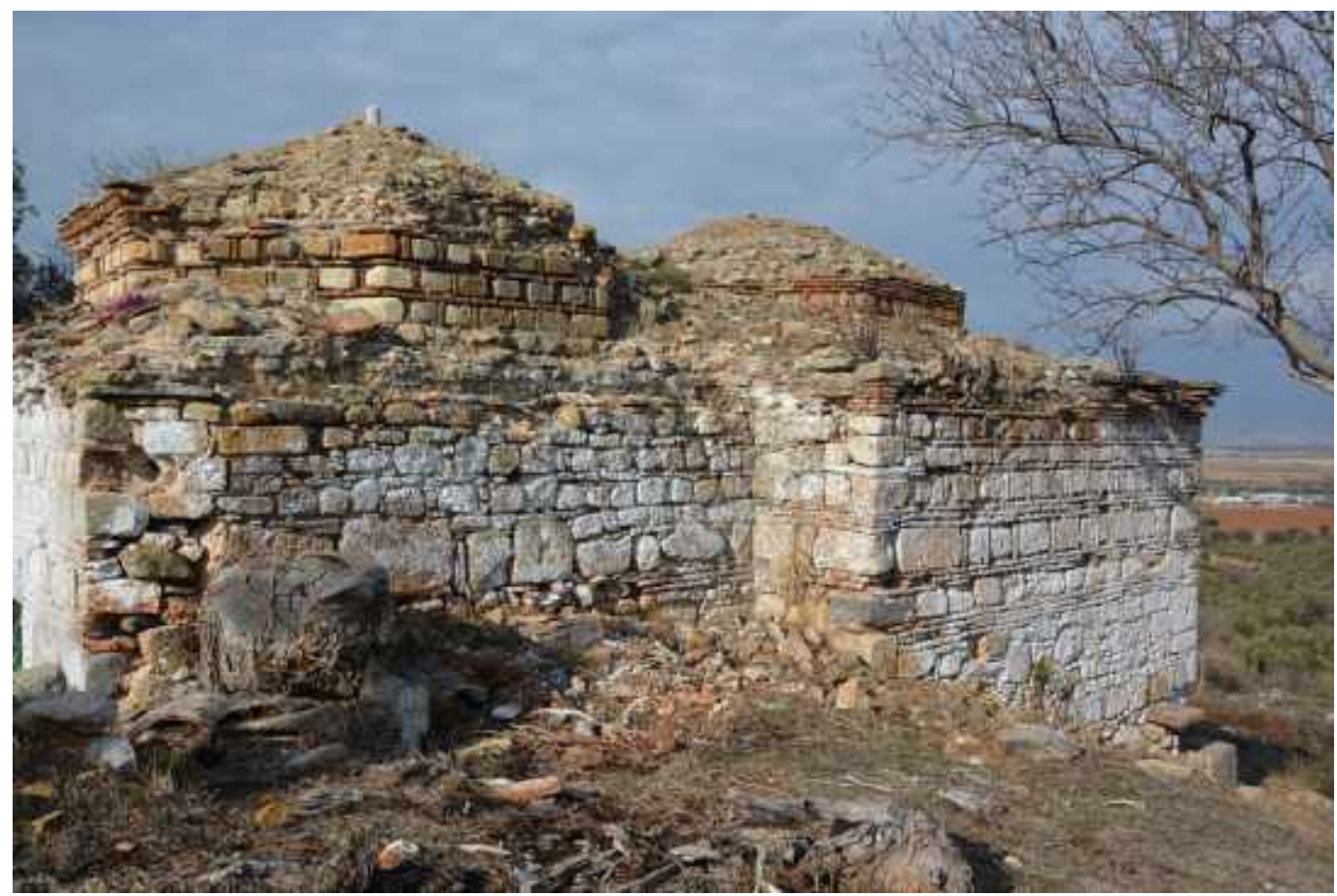

Resim 8-Sar1 Dede Türbesi. Doğu cephesi.

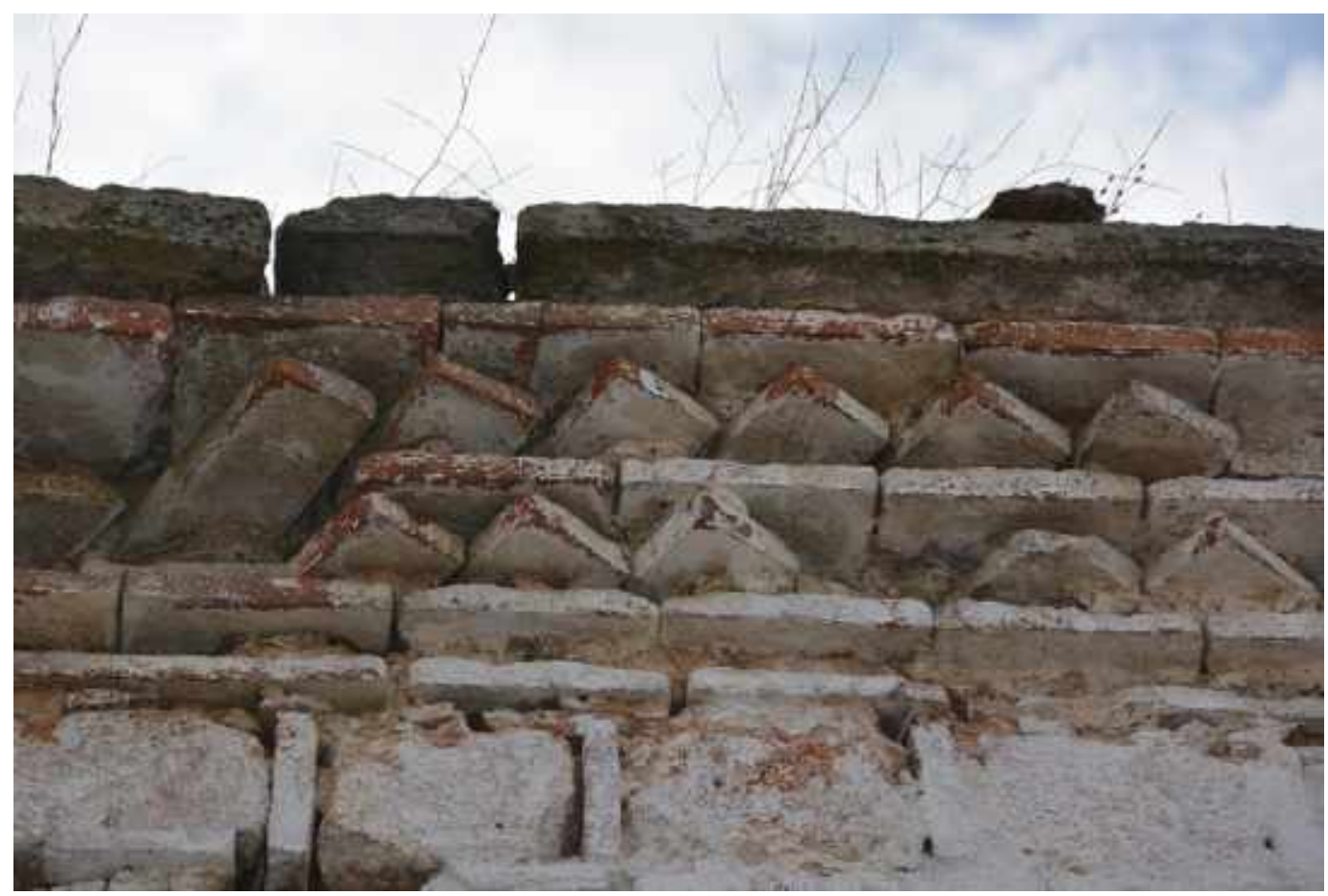

Resim 9-Sarı Dede Türbesi. Saçaklardan ayrıntı. 


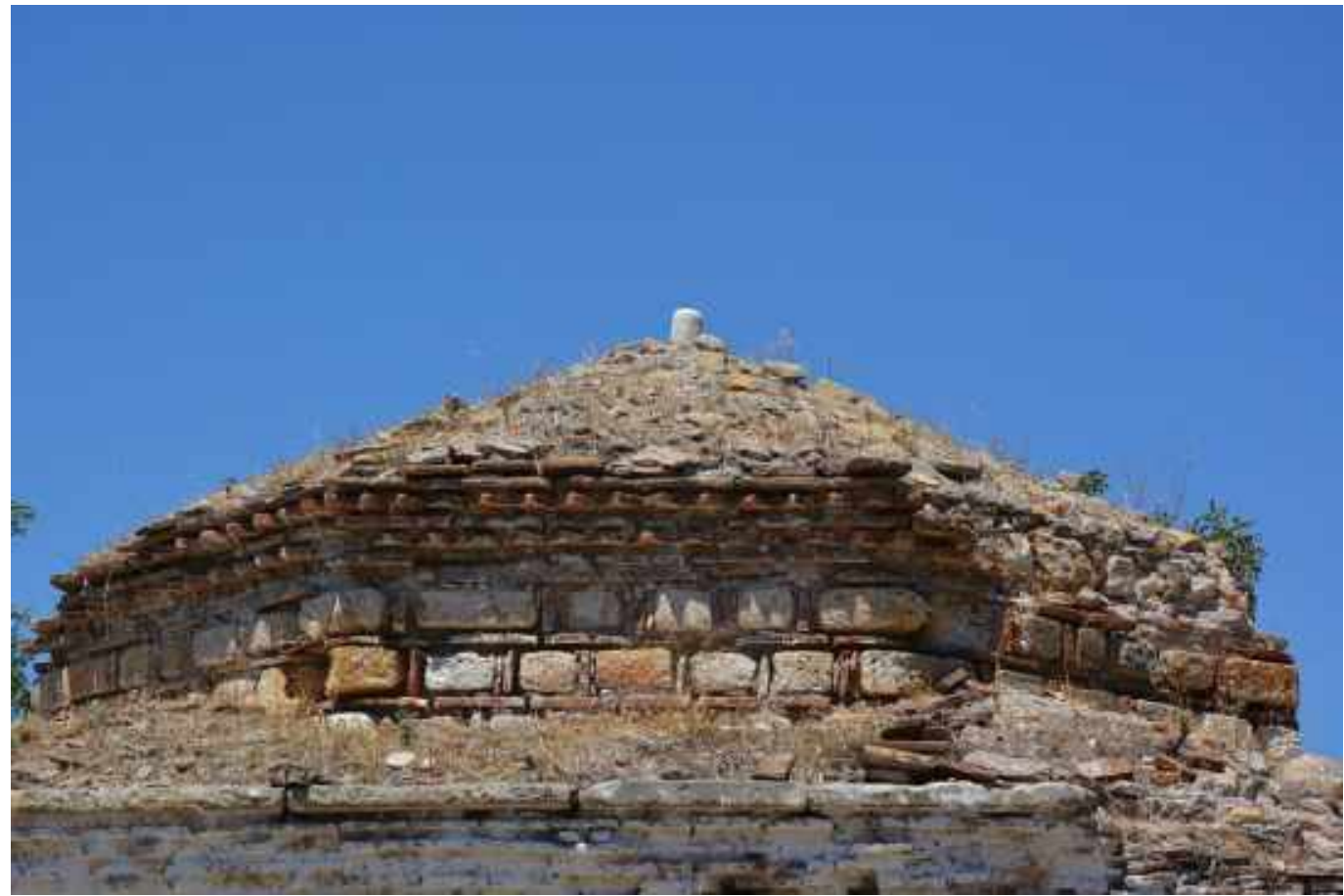

Resim 10-Sarı Dede Türbesi. Ana mekânın kasnak ve kubbesi.

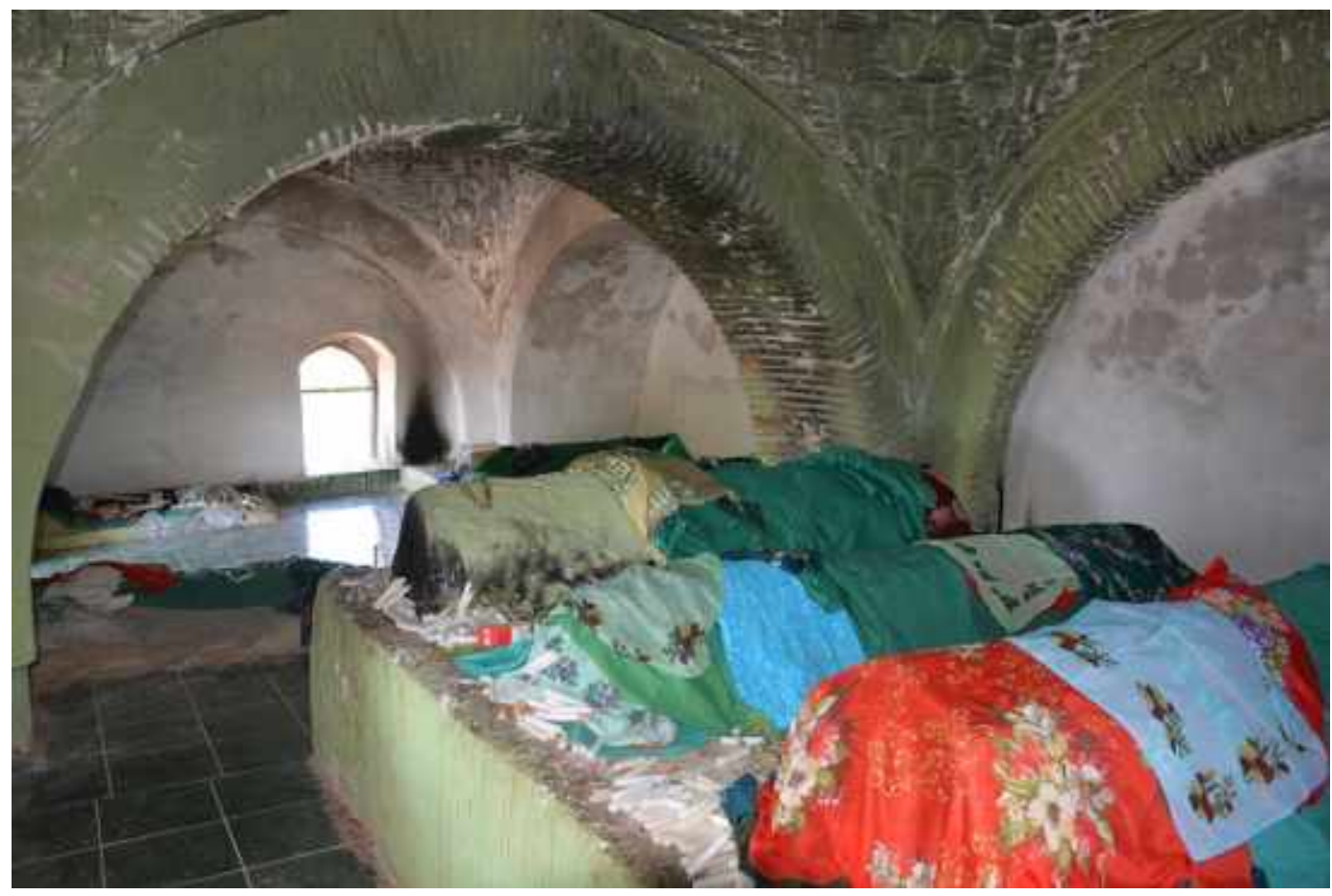

Resim 11-Sarı Dede Türbesi. İçten genel görünüş. 


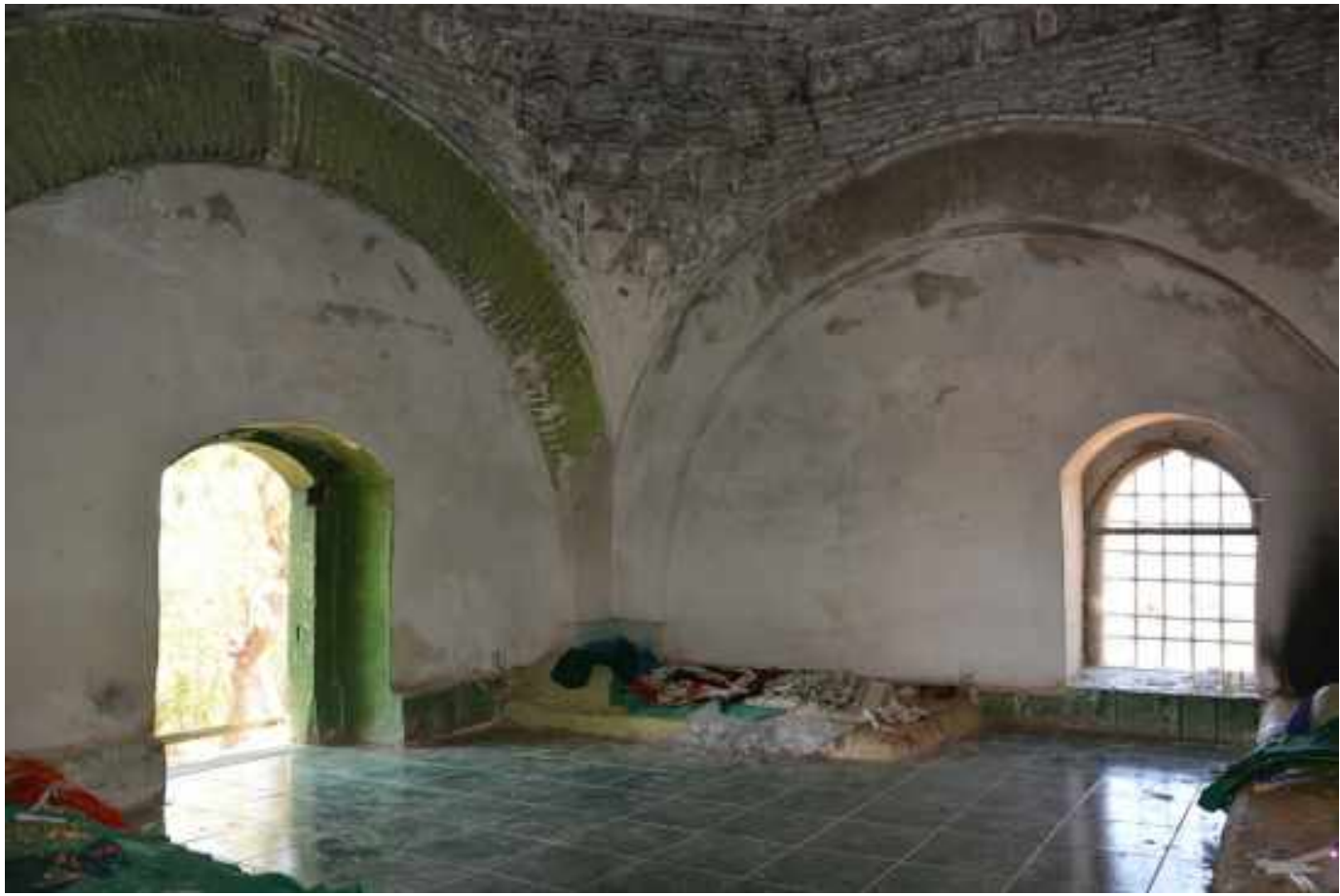

Resim 12-Sarı Dede Türbesi. Ön mekân.

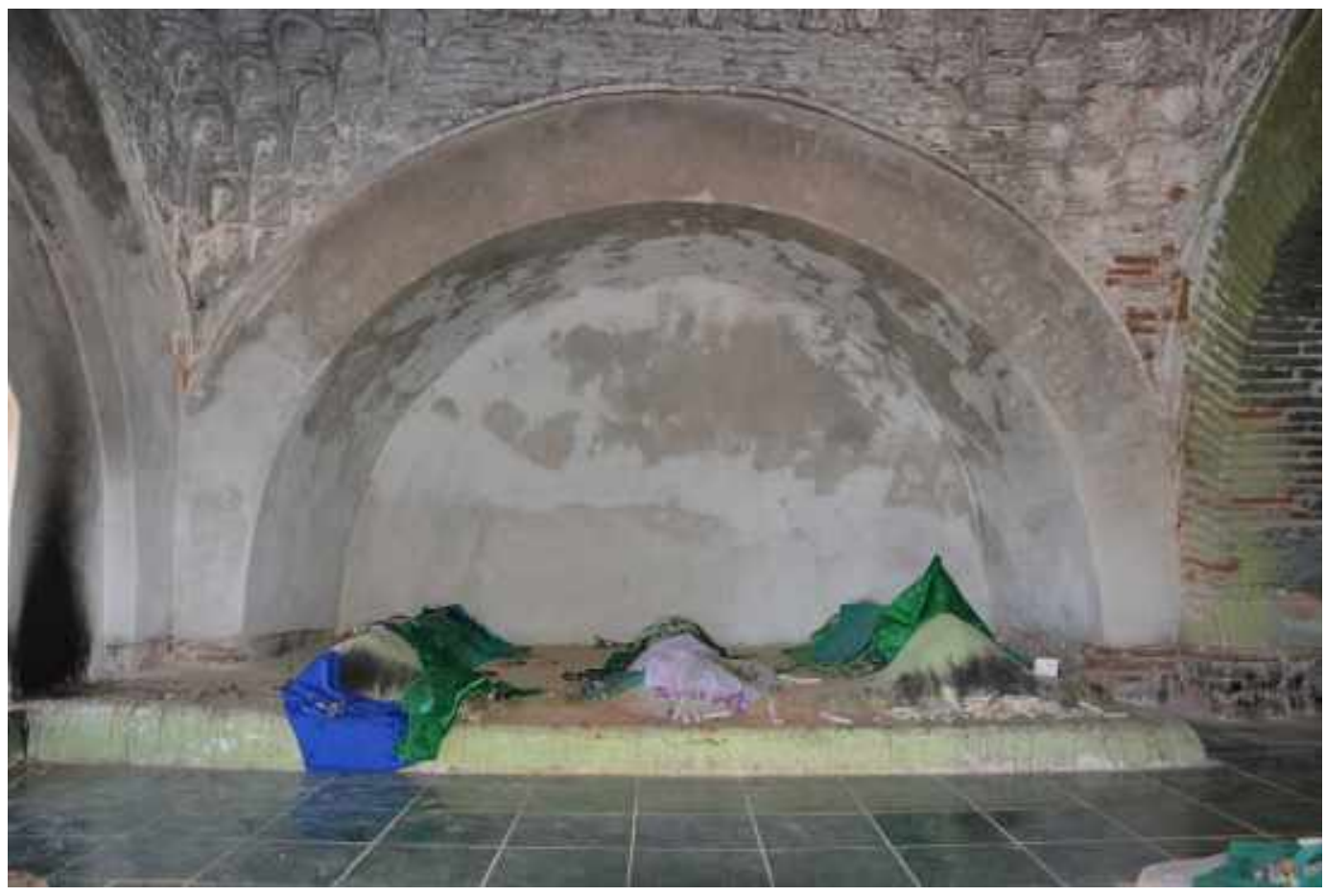

Resim 13-Sarı Dede Türbesi. Ön mekânın doğu kesimi. 


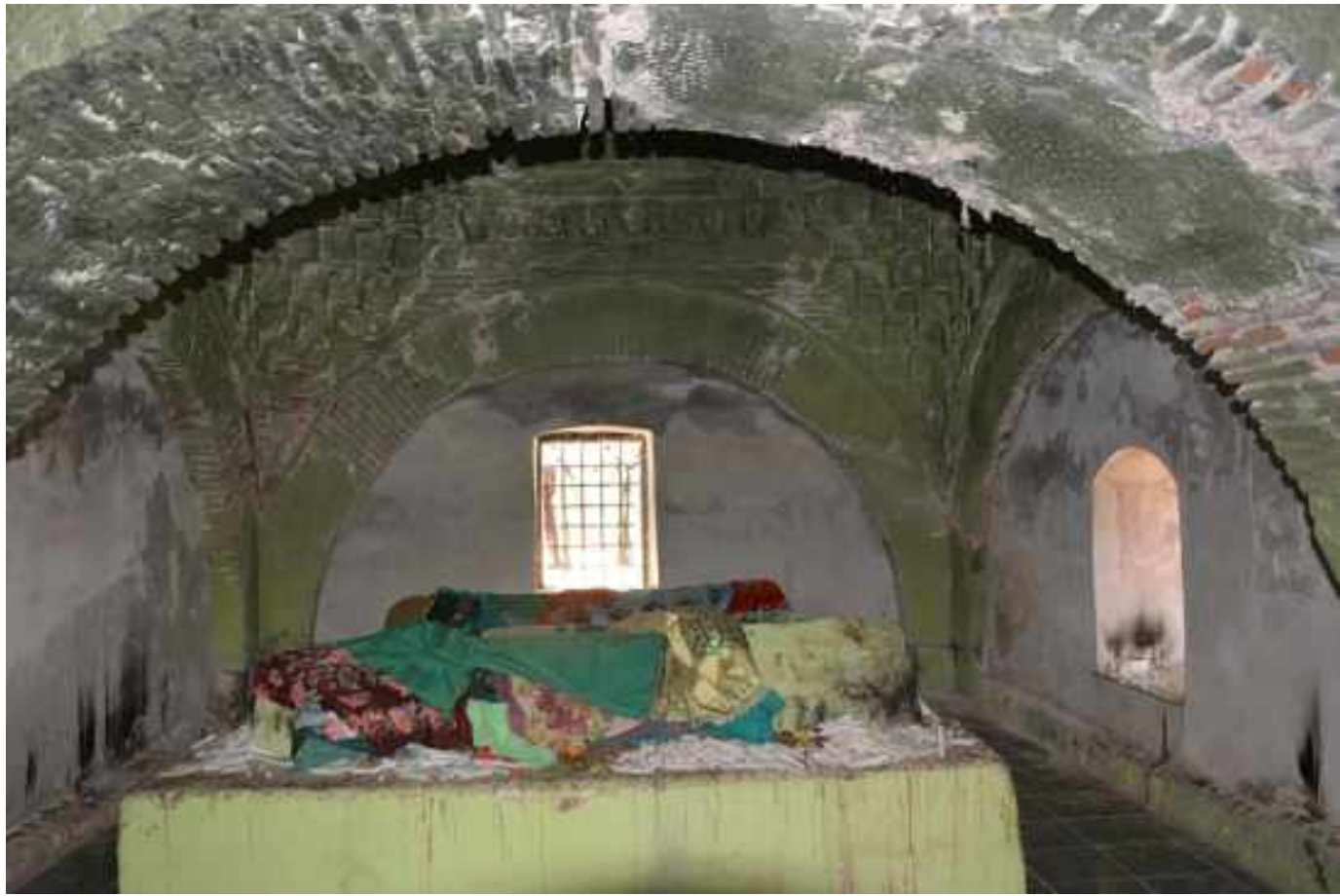

Resim 14-Sarı Dede Türbesi. Ana mekân.

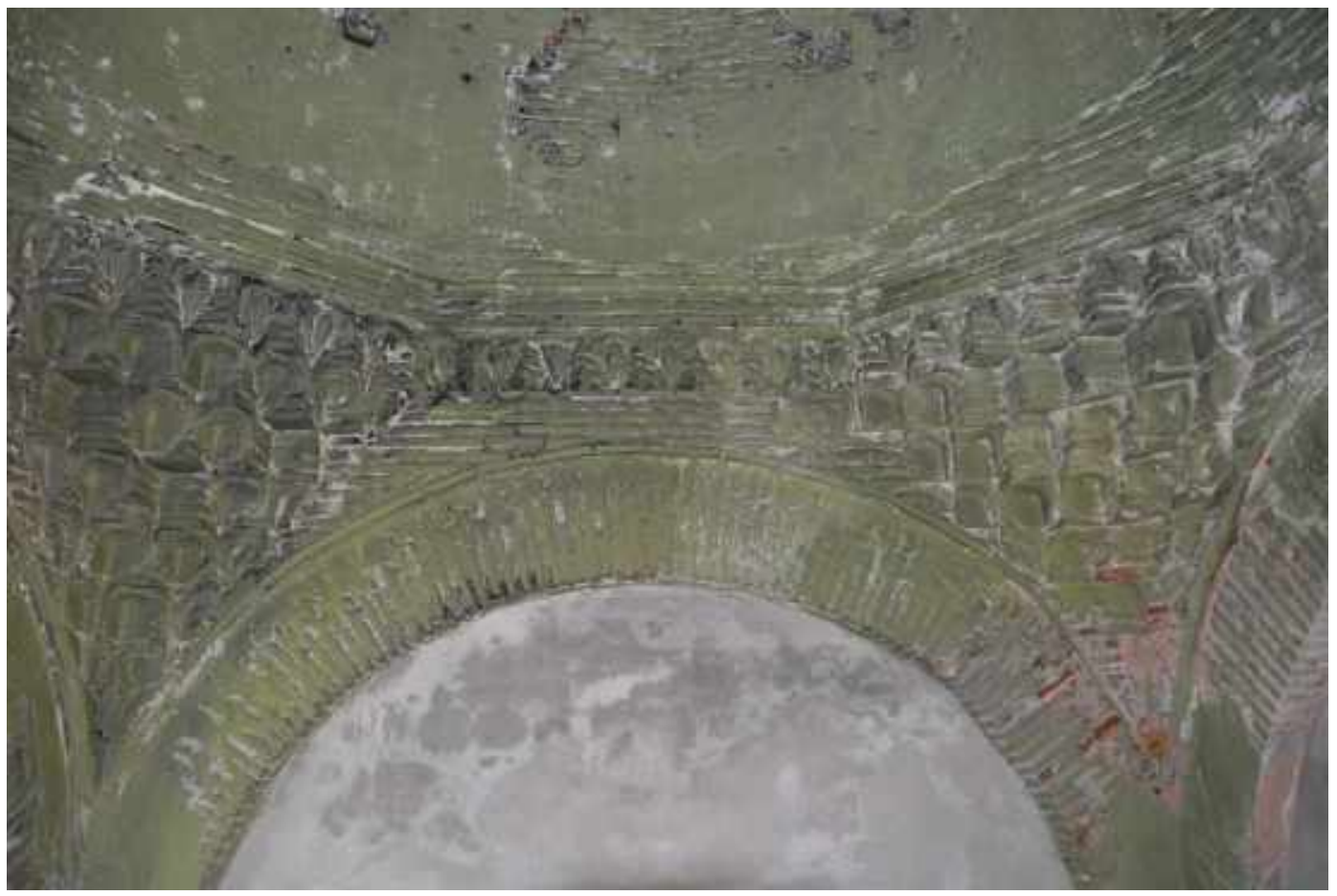

Resim 15-Sarı Dede Türbesi. Kubbe geçişlerinden. 


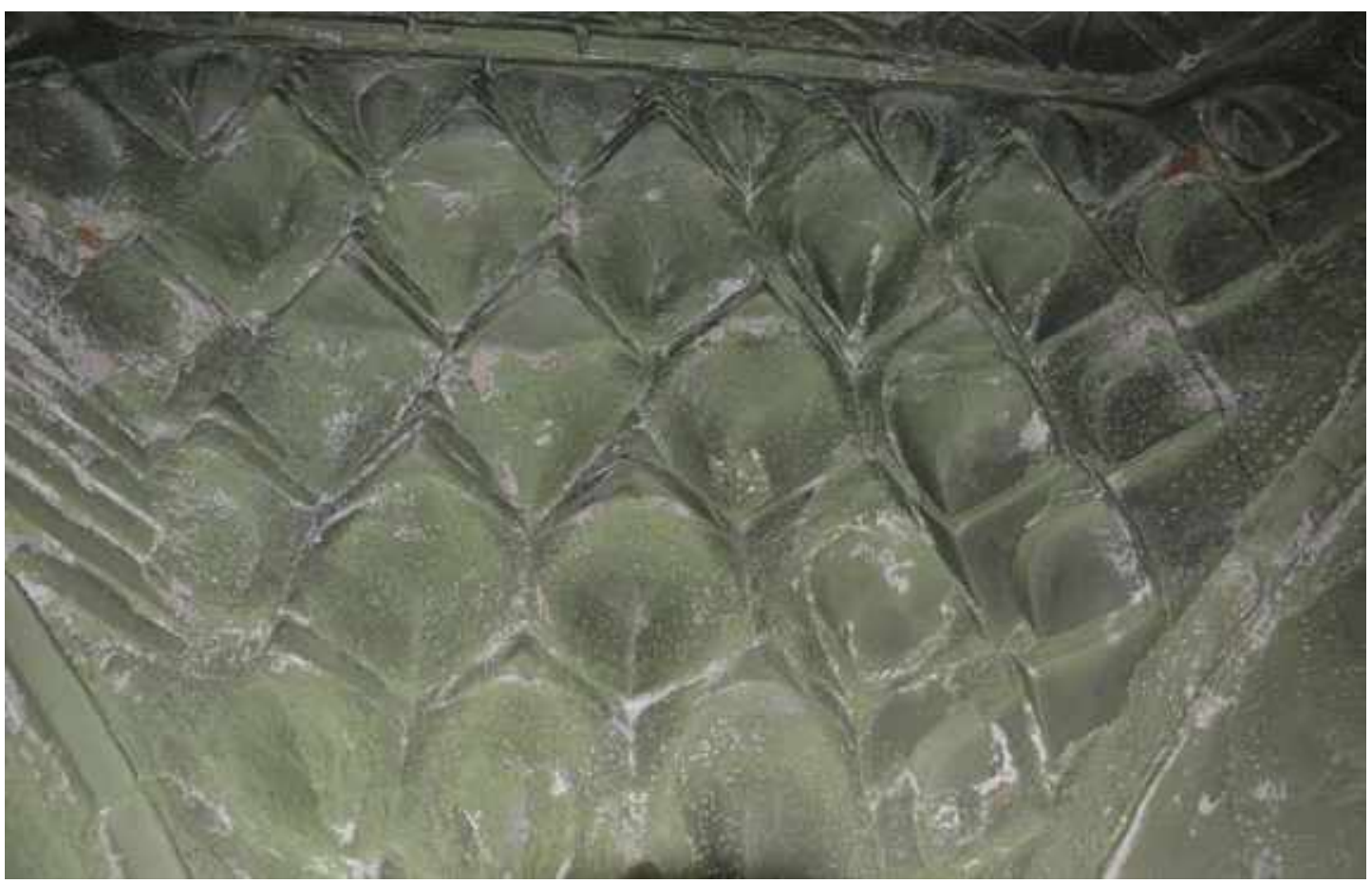

Resim 16-Sarı Dede Türbesi. Kubbe geçişlerinden ayrıntı. 